\title{
Management of Severe Pancreaticoduodenal Injuries
}

\author{
Tanka Prasad Bohra, ${ }^{1}$ Mukund Raj Joshi, ${ }^{1}$ Anuj Parajuli, ${ }^{1}$ Gausan Ratna Bajracharya' \\ 'Department of Surgery, Kathmandu Medical College Teaching Hospital, Kathmandu, Nepal.
}

\section{ABSTRACT}

Severe pancreaticoduodenal injuries are rare and no surgeon and institute get enough number of cases to acquire expertise. Hence, the management of such injuries remains controversial. We report a case of 28 years male who sustained a severe pancreaticoduodenal injury and was managed with emergency pancreaticoduodenectomy with immediate reconstruction. Various approaches have been described in literature with variable outcome. Damage control strategy seems to be most useful approach and major resection should be a part of debridement whenever required. Immediate reconstruction can be carried out safely if patients remain hemodynamically and metabolically stable.

Keywords: damage control surgery; pancreaticoduodenectomy; severe pancreaticoduodenal injuries.

\section{INTRODUCTION}

Pancreaticoduodenal injuries are rare with overall recurrence rate of $1-2 \%$ of abdominal trauma. ${ }^{1}$ This low incidence limits the opportunity for any surgeon and institute to gain adequate experience in managing such injuries. Hence management still remains controversial and various approaches are described in literature which includes complex repair, external drainage to pancreaticoduodenectomy..$^{2-4}$

\section{CASE REPORT}

A 28 years, male who was pillion rider on motorbike presented to Emergency department, Kathmandu Medical College Teaching Hospital, Sinamangal, Kathmandu with alleged history of road traffic accident when the bike was hit by minibus two hours prior.
He was complaining of pain over epigastrium and had history of brief loss of consciousness. His blood pressure and pulse rate was normal on arrival but suddenly fell during initial evaluation which improved with fluid resuscitation. He had tenderness in epigastrium and other physical examinations were normal. Patient had haemoglobin of $8.2 \mathrm{gm} \%$ and Focused Assessment by ultrasound at emergency revealed fluid in peritoneal cavity.

Diagnosis of blunt trauma abdomen with haemoperitoneum was made, contrast enhanced computed tomogram (CECT) abdomen was done as patient remained relatively stable. CECT abdomen revealed free fluid and air in peritoneal cavity. Active

Correspondence: Dr. Tanka Prasad Bohara, Department of Surgery, Kathmandu Medical College Teaching Hospital, Kathmandu, Nepal. Email: tankaprasad.bohara@gmail.com, Phone No: +9779841352378 . 
contrast extravasation was seen in pancreatic head region with laceration in uncinate process and head of pancreas associated with periduodenal hematoma with transection of Duodenum at level of D1 and D3/ D4 segment (Figure 1 and 2). With diagnosis of Grade $\mathrm{V}$ pancreaticoduodenal injury, decision was taken for emergency laparotomy.

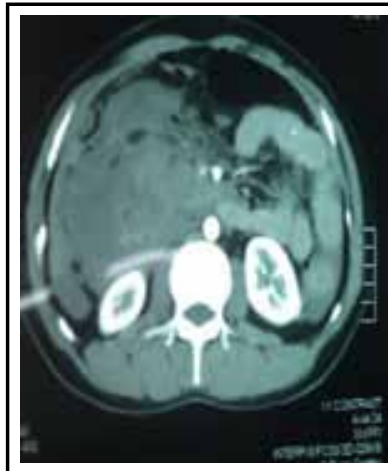

Figure.1 CECT abdomen axial section.

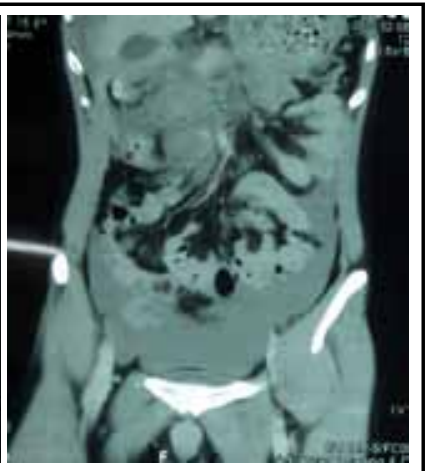

Figure.2 CECT abdomen sagittal section.
Condition and severity of injury, need for immediate operation, high risk involved was discussed with patient's relatives. With written informed consent emergency laparotomy was done. Operative findings included haemoperitonem (about two litres), active bleeding from tributaries of superior mesenteric vein and branches of gastroduodenal artery which were taken control of first. There was complete transection of duodenum at level of D1 and D3 with retroduodenal hematoma, with transection of uncinate process of pancreas and laceration of head of pancreas (Figure 3 and 4).

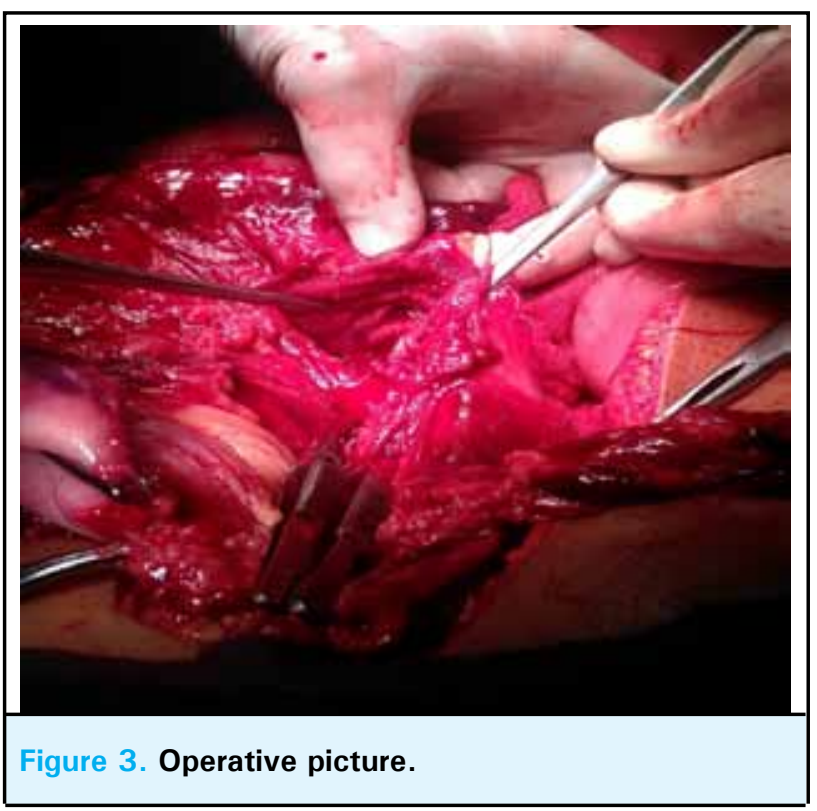

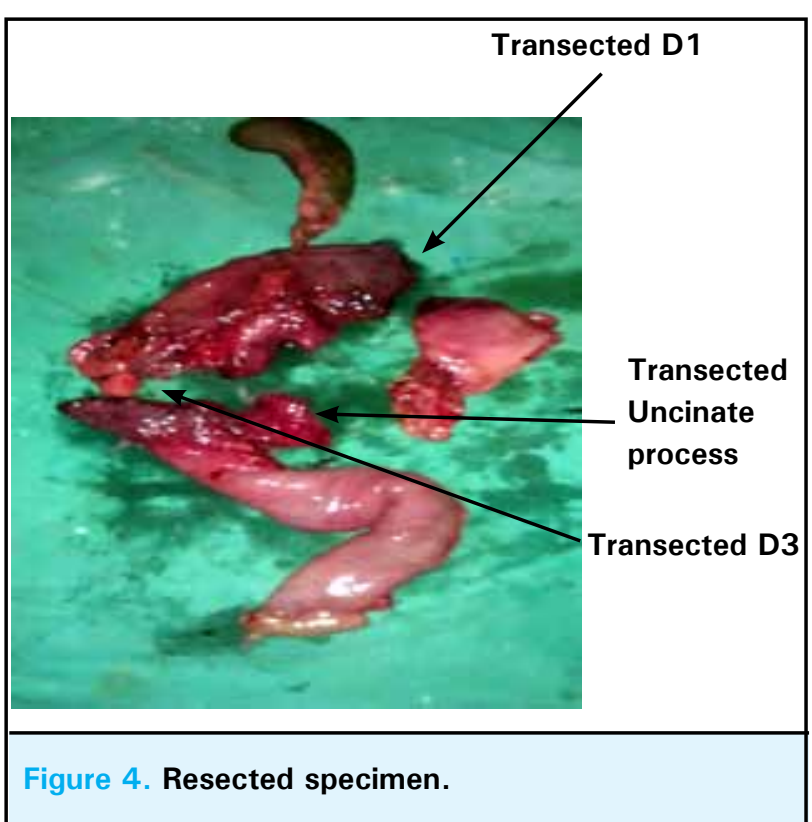

The transected part of duodenum and head of pancreas were severely devitalized that precluded any local repair and reconstruction. So, intra-operative decision was taken to perform pancreaticoduodenctomy. As the patient was relatively stable, reconstruction (pancreaticogastrostomy, hepaticojejunostomy, gastrojejeunostomy and feeding jejunostomy) was also done. Duration of operation was six hours and estimated surgical blood loss was $500 \mathrm{ml}$.

Patient was treated in ICU for four days postoperatively. Post-operative period was uneventful expect for superficial surgical site infection which was treated with drainage. He was discharged on $14^{\text {th }}$ post-operative day and doing well in four months follow up.

\section{DISCUSSION}

Severe pancreaticoduodenal injuries are rare and no surgeon and institute get enough number of cases to acquire expertise. The low incidence of these injuries is attributed to strategic retroperitoneal location of the organ, which is again responsible for delayed diagnosis of this condition because initial clinical symptoms and signs are often deceptive. High index of suspicion in key to early diagnosis of these condition.

Pancreaticoduodenal injuries are more common during penetrating trauma but also occurs as a consequence of blunt trauma. ${ }^{5}$ These injuries are often associated with multiple intra-abdominal injuries, mostly vascular $(27.6 \%)$, which are responsible for early deaths. ${ }^{1,6}$ When patients present with clear indication for laparotomy or when patient remain unstable despite adequate 
resuscitation, no further investigations are required and patient is taken for emergency laparotomy where proper assessment of extent of injuries is done. If the patient is hemodynamically stable and has subtle clinical signs then high index of suspicion is must because if these injuries are missed initially they are responsible for late mortality because of sepsis and other complications. ${ }^{7}$ Contrast enhanced computed tomography should be done to evaluate the severity, extent of injuries and need of immediate laparotomy. Severe pancreaticoduodenal injuries are classified as Grade $\mathrm{V}$ according to Organ Injury Scaling (OIS) committee of American Association of Surgery for trauma (Table 1 and 2 ). ${ }^{8}$

\begin{tabular}{|c|c|c|}
\hline Grade & Type & Description \\
\hline I & $\begin{array}{l}\text { Haematoma } \\
\text { Laceration }\end{array}$ & $\begin{array}{l}\text { Minor contusion without } \\
\text { duct injury } \\
\text { Superficial laceration } \\
\text { without duct injury }\end{array}$ \\
\hline II & $\begin{array}{l}\text { Haematoma } \\
\text { Laceration }\end{array}$ & $\begin{array}{l}\text { Major contusion without } \\
\text { duct injury or tissue loss } \\
\text { Major tissue laceration } \\
\text { without duct injury }\end{array}$ \\
\hline III & Laceration & $\begin{array}{l}\text { Distal transection or } \\
\text { parenchymal injury }\end{array}$ \\
\hline IV & Laceration & $\begin{array}{l}\text { Proximal transection or } \\
\text { parenchymal injury }\end{array}$ \\
\hline V & Laceration & $\begin{array}{l}\text { Massive disruption of } \\
\text { pancreatic head }\end{array}$ \\
\hline
\end{tabular}

Table 2. Duodenal organ injury scale.

\begin{tabular}{|c|c|c|}
\hline Grade & Type & Description \\
\hline \multirow[t]{2}{*}{ I } & Haematoma & $\begin{array}{l}\text { Involving single portion of } \\
\text { duodenum }\end{array}$ \\
\hline & Laceration & $\begin{array}{l}\text { Partial thickness, no } \\
\text { perforation }\end{array}$ \\
\hline \multirow{2}{*}{ II } & Haematoma & $\begin{array}{l}\text { Involving more than one } \\
\text { portion }\end{array}$ \\
\hline & Laceration & $\begin{array}{l}\text { Disruption }<50 \% \quad \text { of } \\
\text { circumference }\end{array}$ \\
\hline III & Laceration & $\begin{array}{l}\text { Disruption } 50-75 \% \text { of D2 } \\
\text { Disruption } 50-100 \% \text { of D1, } \\
\text { D3, D4 }\end{array}$ \\
\hline IV & Laceration & $\begin{array}{l}\text { Disruption }>75 \% \text { of } \mathrm{D} 2 \\
\text { Involving ampulla or common } \\
\text { bile duct }\end{array}$ \\
\hline \multirow{2}{*}{ V } & Laceration & $\begin{array}{l}\text { Massive disruption of } \\
\text { duodenopancreatic complex }\end{array}$ \\
\hline & Vascular & $\begin{array}{l}\text { Devascularization of } \\
\text { duodenum }\end{array}$ \\
\hline
\end{tabular}

Surgical management remains controversial and various approach has been described in literature which includes complex repair, external drainage to pancreaticoduodenctomy (PD) with or without immediate reconstruction. ${ }^{2-4}$ Management of such trauma should be individualized according to patient's hemodynamic condition, extent of injuries, associated injuries and surgeon's expertise.

Aim of operative management in these patients should be damage control surgery to prevent patient going into metabolic failure and triad of death of acidosis, coagulopathy and hypothermia. Control of active haemorrhage is the primary concern followed by limitation of contamination, debridement of devatalised tissue and external drainage of pancreatic and biliary secretions.

PD for Grade $V$ pancreaticoduodenal injuries has been described with incidence of $4 \%$ to $5 \%$ for patient's pancreatic and duodenal injury. ${ }^{9,10}$ PD in these severe injuries should be reserved for uncontrolled bleeding from pancreatic head, injuries to proximal pancreatic duct and ampullary injuries which preclude reconstruction and extensively devitalized duodenum and pancreatic head. ${ }^{11}$ We had to perform PD in our patient because of bleeding and severely devitalized pancreatic head, uncinate process of pancreas and duodenum where no local repair was feasible. PD in our patient was essentially a part of debridement.

Basic principal in the management of complex pancreaticoduodenal injuries is to avoid complex and lengthy procedure in an unstable patient and if surgeons are not experienced in performing complex resection and reconstruction. ${ }^{12}$ In a relatively stable patient, PD with or without reconstruction is feasible. ${ }^{3,13} \mathrm{PD}$ should be part of debridement and if patient remain stable and the surgeons are experienced in performing complex reconstruction, PD with immediate reconstruction can be safely accomplished thereby abolishing the need of second major operation.

However, if condition are not favorable, a staged procedure has been proposed which includes control of bleeding, biliary and pancreatic external drainage, stapling and suturing of stomach, jejunal and pancreatic stump and feeding jejunostomy followed by reconstruction in second operation when abdominal sepsis has been resolved and patient is clinically fit. $9,11,14-15$

There are few differences in performing PD and reconstruction in trauma setting. Uncinate process need not be completely removed as in malignant cases and this relatively simplifies the operation. ${ }^{2}$ Gall bladder can 
be used for bilio-enteric reconstruction in the presence of undilated biliary ducts. ${ }^{2}$ Pancreaticogastrostomy has been advocated as an exceptionally safe in these patients though the experience in trauma is limited. ${ }^{16}$

Severe pancreaticoduodenal injuries are rare. Literature describes various approaches ranging from local repair, external drainage to PD with or without reconstruction. PD should be essentially part of debridement of devitalized tissue. Immediate reconstruction is feasible in relatively stable patient when surgeons are experienced in performing complex reconstruction else a staged procedure is advocated.

\section{ACKNOWLEDGEMENTS}

We would like to thank our patient for his consent to report the case.

\section{REFERENCES}

1. Glancy KE. Review of pancreatic trauma. West J Med. 1989 Jul;151(1):45-51.

2. Degiannis E, Glapa M, Loukogeorgakis SP, Smith MD. Management of pancreatic trauma. Injury. 2008 Jan;39(1):21-9.

3. De Kerpel W, Hendrickx T, Vanrykel JP, Aelvoet C, De Weer F. Whipple procedure after blunt abdominal trauma. J Trauma. 2002 Oct;53(4):780-3.

4. Krige JE, Nicol AJ, Navsaria PH, Jones O, Bornman PC. Emergency pancreaticoduodenectomy for complex pancreatic trauma. HPB Surg. 2005;7:104.

5. Wilson RH, Moorehead RJ. Current management of trauma to the pancreas. Br J Surg. 1991 Oct;78(10):1196-202.

6. Jurkovich GJCCJ. Pancreatic trauma. Surg Clin North Am. 1990;70:575-93.

7. Bradley EL 3rd, Young PR Jr, Chang MC, Allen JE, Baker CC, Meredith $\mathrm{W}$ et al. Diagnosis and initial management of blunt pancreatic trauma: guidelines from a multiinstitutional review. Ann Surg. 1998 Jun;227(6):861-9.

8. Moore EE, Cogbill TH, Malangoni MA, Jurkovich GJ, Champion HR, Gennarelli TA et al. Organ injury scaling, II: Pancreas, duodenum, small bowel, colon, and rectum. J Trauma. 1990 Nov;30(11):1427-9.
9. AsensioJA, PetroneP, RoldánG,Kuncir E, Demetriades D. Pancreaticoduodenectomy: a rare procedure for the management of complex pancreaticoduodenal injuries. J Am Coll Surg. 2003 Dec;197(6):937-42.

10. Lin BC, Chen RJ, Fang JF, Hsu YP, Kao YC, Kao JL. Management of blunt major pancreatic injury. J Trauma. 2004 Apr;56(4):774-8.

11. Gupta V, Wig JD, Garg H. Trauma pancreaticoduodenectomy for complex pancreaticoduodenal injury. Delayed reconstruction. JOP. 2008 Sep;9(5):618-23.

12. Rickard MJ, Brohi K, Bautz PC. Pancreatic and duodenal injuries: keep it simple. ANZ J Surg. 2005 Jul;75(7):581-6.

13. Eastlick L, Fogler RJ, Shaftan GW. Pancreaticoduodenectomy for trauma: delayed reconstruction: a case report. J Trauma. 1990 Apr;30(4):503-5.

14. Koniaris LG, Mandal AK, Genuit T, Cameron JL. Two-stage trauma pancreaticoduodenectomy: delay facilitates anastomotic reconstruction. J Gastrointest Surg. 2000 Jul-Aug;4(4):366-9.

15. Tuech JJ, Pessaux P, Rege N, Bergamaschi R, Arnaud JP. Emergency Pancreaticoduodenectomy with Delayed Reconstruction for Bleeding: A Life Saving Procedure. Int J Gastrointest Cancer. 2001;29(1):59-62.

16. Morris DM, Ford. Pancreaticogastrostomy: preferred reconstruction for Whipple resection. J Surg Res. 1993 Feb;54(2):122-5. 